\title{
PENGUATAN KAPASITAS PEREMPUAN SEBAGAI STEAKHOLDER DALAM PENANGGULANGAN KORBAN BENCANA BANJIR DI PANGKALAN
}

\author{
Suyito \\ Sekolah Tinggi Ilmu Politik Raja Haji Tanjung Pinang, titosuyito@yahoo.co.id \\ Redni Putri Meldianto \\ IAIN Bukittinggi, rednimeldiantoputri@gmail.com \\ Siti Anisa \\ IAIN Bukittinggi,sa_anisa@yahoo.com \\ Tesi Prima \\ IAIN Bukittinggi,tesi_prima@yahoo.com
}

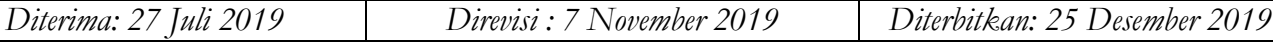

\begin{abstract}
This article examines the fulfillment of women's rights in disaster situations that occur in Pangkalan Koto Baru District. The flood disasters occurred in the study area had an impact on women and men, especially when in refugee camps when the disaster occurred. Stakeholders as the ones who is responsible for handling problems in this refugee camp should be professional person in handling people based on gender and age. This has become very important act because women are included in vulnerable groups and require special treatment on emergency. It turns out that women are more vulnerable groups as victims of disasters than men. Based on these conditions, women need variety of strengths dealing with disasters, in order to rise from the threats as the impact of the disaster. The strengthening capacity of women was related to the strengthening of economic, psychological, and mentality. It was done to fulfill the women's rights when disasters happen and its impacts.
\end{abstract}

Keywords: Empowerment, Women, Disaster, Stakeholder

\begin{abstract}
Abstrak
Artikel ini mengkaji tentang pemenuhan hak perempuan dalam situasi bencana yang terjadi di Kecamatan Pangkalan Koto Baru. Bencana banjir yang terjadi di wilayah kajian memiliki dampak terhadap perempuan dan laki-laki, terutama ketika berada di pengungsian ketika bencana tersebut terjadi. Stekholder sebagai salah satu yang bertanggungjawab dalam menangani masalah di pengungsian ini, semestinya mempunyai penanganan yang professional berdasarkan gender dan usia. Hal ini mnejadi sangat penting untuk dilakukan karena perempuan termasuk dalam kelompok rentan dan membu tuhkan penanganan khusus pada saat tanggap darurat. Ternyata perempuan kelompok yang lebih rentan sebagai korban bencana dibandingkan laki-laki. Berdasarkan kondisi dan situasi tersebut, maka perempuan perlu dilakukan berbagai peguatan dalam mengadapi bencana, sehingga perempuan bias bangkit dari ancaman-ancaman dari dampak bencana tersebut. Penguatan kapasitas perempuan, yang dilakukan berkaitan dengan penguatan-penguatan ekonomi, psikologis, dan mentalitasnya.Penguatan ini sebagai salah satu bentuk yang harus dilakukan untuk pemenuhan hak perempuan ketika menghadapi bencana dan dampaknya.
\end{abstract}

Keywords:Pemberdayaan, Perempuan, Bencana, Sebagai Steakholder 


\section{Latar Belakang}

Provinsi Sumatra barat merupakan daerah yang rawan bencana, karena terletak berada pada pertemuan lempeng IndoAustralian dan Eropa Asia di Samudra Hindia sebelah barat kepulauan Mentawai serta dilaluai oleh patahan Semangka mulai dari Solok Selatan Sampai Pasaman yang sangat rentang terhadap bencana gempa bumi dan tsunami. Oleh karena itu seluruh wilayah di Provinsi Sumatra Barat sangat rawan bencana.

Potensi bencana yang menimpa Sumatra Barat terdiri dari gerakan tanah longsor, banjir bandang, tsunami, gempa darat dan laut. Untuk kabupaten 50 Kota terdapat dua potensi bencana, yaitu tanah longsor dan banjir. Kedua bencana tersebut terjadi setiap tahun pada wilayah 50 kota.

Pangkalan Koto Baru Kabupaten 50 Kota salah satu kawasan yang sering dilanda oleh banjir dan tanah longsor di Kabupaten 50 Kota adalah Kecamatan Pangkalan Koto Baru. Kondisi wilayah Disekitar Pangkalan Koto Baru terletak didataran rendah dan ditepi sungai besar. Kabupaten 50 Kota merupakan daerah yang mengalami tingkat peningkatan dan frekuensi kejadian bencana yang besar. Salah satunya adalah bencana banjir hal ini terjadi karena tingginya intensitas curah hujan dan konversi kawasan hutan menjadi penggunaan lain terjadinya faktor banjir. Bencana banjir dan tanah longsor di Kecamatan Pangkalan Koto Baru Kabupaten 50 Kota telah mengakibatkan kerugian fisik dengan runtuhnya beberapa bangunan, tempat tinggal, sekolah rusak, sarana dan prasarana transportasi bahkan hilangnya harta benda. Selain itu banjir juga mengakibatkan kerugian tidak langsung seperti: tergangunya komunikasi, pendidikan, kesehatan, kegiatan bisnis.

Dengan begitu mengakibatkan menimbulkan beban ekonomi bagi masyarakat dan beban kerugian insfrastruktur bagi pemerintah daerah.
Bencana yang terjadi sering kali menimbulkan banyak korban. Korban dari bencana tersebut, diantaranya adalah perempuan. Perempuan 14 kali lebih berisiko untuk menjadi korban bencana dibandingkan dengan laki-laki. Hal ini disebabkan oleh adanya naluri perempuan yang ingin melindungi keluarga dan anak-anaknya, sehingga seringkali mengabaikan keselamatan diri mereka. ${ }^{1}$

Ada beberapa kelompok yang lebih rentan mendapatkan imbasnya bencana yakni, perempuan, anak-anak, para usia lanjut dan penyandang cacat. Mereka merupakan kelompok yang paling dominan menjadi korban pada saat bencana. Keberadaan mereka selalu di ruang domestik dan sangat sulit untuk mendaptkan akses informasi pada saat bencana datang. Hasilnya mereka kerap menjadi sasaran amukan bencana yang datang tanpa mengenal waktu. Secara fisik perempuan memiliki kondisi yang relatif lemah dari pada laki-laki.

\section{Metodologi}

Penelitian ini menggunakan metode deskriptif kualitatif dengan analisis gender CVA (capacities and Vulnerabilities Analysis). Dalam menentuan informasi ditentukan dengan snowball sampling dengan pengumpulan data mengunakan teknik observasi dan in depth interview. Key informant dalam penelitian ini adalah Kepala Jorong Pangkalan Koto Baru 50 Kota yang daerahnya sangat rawan bencana banjir dan tanah longsor. Dalam hal ini penelitian ini bertujuan untuk menganalisis penguatan kapasitas perempuan sebagai steakholder dalam penangulangan bencana banjir di pangkalan koto baru 50 Kota.

\section{Pembahasan}

Pada saat sekarang ini masih sangat minimnya pengetahuan masyarakat akan

${ }^{1}$ Nurtjaho dkk. 2011. "Peran Perempuan dalam Pembangunan Berkelanjutan Woment In Susti Nable Development". Tidak ada tempat terbit. Hal 56 
datanganya bencana, karena ketidaksiapan untuk menghadapi bencana yang datang secara tiba-tiba, yang terjadi pada masyarakat adalah suatu kepanikan. Dan pada saat itulah tangung jawab seorang perempuan menjadi lebih berat, pada saat itu dia harus menyelamatkan dirinya sendiri, anak-anak dan keluarga. Karena rendahnya pengetahuan perempuan pada saat bencana dimana pada saat bencana datang perempuan lebih mengfokuskan kepada barang-barang berharga dibandingkan dengan dirinya sendiri dan keluarganya.

Banyak hal yang menyebabkan seorang perempuan untuk menjadi korban bencana, yang Pertama adanya suatu konstruksi yang dibentuk oleh masyarakat bahwa perempuan harus lebih dahulu untuk menyelamatkan keluarga dibandingkan dirinya sendiri. Kedua, sering kali perempuan tidak memiliki pengetahuan yang kuat dalam latihan penyelamatan korban bencana, hal dikarenakan adanya nilai-nilai budaya yang lebih memfokuskan perempuan untuk mengurus urusan domestik, sehingga sangat sulit bagi perempuan untuk bisa mengakses dunia luar. Ketiga, minimnya pengetahuan lokal perempuan tentang gejala awal terjadinya bencana.

Hal ini dikarenakan minimnya pengetahuan sehingga perempuan lebih rentan untuk menjadi korban bencana. Dalam menghadapi persoalan bencana perempuan jauh lebih rentan menjadi korban bencana dari pada laki-laki, hal ini banyak disebut dalam berbagai literatur yang mengkaji gender dan bencana menyatakan bahwa masalah ekonomi, ras/etnis dan usia menyebabkan perempuan berada dalam kondisi lebih beresiko dari pada laki-laki. ${ }^{2}$ Perempuan selalu berada dalam kondisi dimarjinalkan oleh laki-laki didalam

2 Ananda Dkk. 2014."Perlindungan Perempuan Korban Bencana". Jurnal Mahasiswa Program Studi Sarjana Kesejahteraan Sosial Universitas Padjadjaran. Departemen Kesejahteraan Sosial. Vol 9. No. ISSN:2339/0042 (p) ISSN:2528/1577 (e) hal 110 kegiatan publik. Perbedaan fisik laki-laki dan perempuan itu tentu adalah dua hal yang berbeda yang tidak akan mungkin untuk disamakan apalagi perempuan selalu dikotomikan sebagai makhluk yang harus dilindungi. Situasi bencana akan selalu berimbas secara langsung kepada seluruh sistem kehidupan masyarakat dan seringkali memberi pengaruh ganda bagi perempuan Meskipun secara fisik bencana terlihat sama namun dampak dan beban yang dirasakan oleh laki-laki dan perempuan akan sangat berbeda pada tingkatan kerentanan masing-masing individu tersebut.

Kondisi rentan tersebut, dalam situasi bencana yang mengakibatkan dan selalu dikonstruksi secara sosial melalui analisis gender. Adanya perbedaan peran berdasarkan jenis kelamin terjadi karena adanya budaya sekitar yang menjadi dasar kebudayaan di dalam masyarakat. Khususnya dalam budaya patriarki yang menginterprestasikan adanya perbedaan hak-hak dan perilaku perempuan didalam masyarakat. Begitu minimnya pengetahuan masyarakat yang salah mengartikan gender dan jenis kelamin. ${ }^{3}$ Gender dapat diartikan sebagai jenis kelamin atau konotasi masyarakat untuk menetukan peran sosial berdasarkan jenis kelamin. Hal ini menyebabkan perempuan selalu ditempatkan berdasarkan sistem patriarki yang membuat perempuan ditempatkan sebagai pemegang tanggung jawab terhadap peran-peran domestik dan perawatan dalam kegiatan masyarakat.

Namun seringkali, peran dan tanggung jawab yang diemban oleh perempuan secara tidak langsung berbenturan dengan keterbatasan mereka dalam mengakses hakhaknya sebagai korban bencana. Tidak terpenuhinya hak-hak pelayanan yang didapatkan oleh perempuan juga disebabkan

${ }^{3}$ Yuliana. 2015."Mengurangi Tingkat Kerentanan Bencana Melalui Kebijakan Mitigasi Berbasis Kebutuhan Gender". Hal 120 
oleh proses asesmen terhadap kerusakan, kehilangan, dan kebutuhan yang sebagian besar dilakukan oleh laki-laki yang mendapatkan umpan balik adalah laki-laki. ${ }^{4}$ Oleh karena itu perlu terlibatnya perempuan dalam membentuk kebijakan penanggulangan bencana yang telah menjadi urgensi yang harus dimuat dalam kebijakan hingga pengimplementasian program penanggulangan bencana dengan memiliki tujuan yang menyelenggarakan pemulihan dampak bencana, dan memiliki program yang andil gender.

Kecenderungan peran perempuan dalam proses penanggulangan bencana yang lebih besar dibandingkan dengan laki-laki adalah suatu bukti bahwa sebenarnya perempuan memiliki kemampuan dalam kapasitas mengelolah bencana. Dalam berbagai studi bencana didaerah rawan bencana seperti Aceh, Padang dan Lombok mengemukakan bahwa perempuan diketiga tempat tersebut lebih mengutamakan keluarga yang memiliki tingkat kepedulian yang lebih tinggi dengan lingkungan sekitar. Hal ini semakin sempurna menyatakan bahwa perempuan memiliki ikatan yang kuat dengan masyarakat dibandingkan laki-laki. ${ }^{5}$ Perempuan adalah salah satu aktor sosial yang berdedikasi dalam penanggapan darurat yang cakap dan mahir dalam mengakses jejaringan sosial informal untuk saling menyebar informasi dan bertukar bantuan.

Sayangnya potensi besar yang dimiliki oleh perempuan tidak mendapatkan respon positif hal ini akibat berlakunya sistem patriarki yang secara eksplisit dan inplisit memperkuat indikasi adanya pemisahan peran antara laki-laki dan perempuan. Peran laki-laki

${ }^{4}$ Enarson. 2000. "Gender ekuiliti work and and disaster reduction: making the connection" $n$. Hal 58

5 Ananda Dkk. 2014.'Perlindungan Perempuan Korban Bencana". Jurnal Mahasiswa Program Studi Sarjana Kesejahteraan Sosial Universitas Padjadjaran. Departemen Kesejahteraan Sosial. Vol 9. No. ISSN:2339/0042 (p) ISSN:2528/1577 (e) hal 112 sebagai penetu tunggal dan sentral yang diklaim sebagai sistem budaya mayoritas di Indonesia yang menimbulkan kesenjangan dan diskriminasi gender dalam interaksi kegiatan manusia . Perempuan di Indonesia pada saat ini masih sangat rendah ikut serta dalam kegiatan publik sehingga semakin mempersempit peluang bagi perempuan untuk hadir dan memegang peran penting dalam bidang pembangunan. Hal ini terjadi karena masih banyak daerah-daerah yang memegang kuat nilai-nilai budaya patriarki sehingga perempuan memiliki keterbatasan hak secara ekonomi, sosial, politik, psikologi bahkan hak pribadi yang seharusnya diputuskan sendiri. ${ }^{7}$ Tindakan untuk memperjuangkan hak-hak perempuan sangat terkendala karena masih minimnya kebijakan hukum terhadap perlindungan perempuan.

Perempuan adalah sekelompok masyarakat yang secara bersamaan menerima dampak bencana sekaligus menghadapi kerentanan yang lebih dibandingkan kelompok lain, namun adanya pembatasan ruang untuk perempuan mendapatkan haknya hal ini semakin menambah deretan panjang ketidakadilan yang dialami perempuan. Dalam pemenuhan kebutuhan dan hak perempuan dalam situasi bencana masih sangat minim maka perlu adanya upaya mendorong kesejahteraan dan keadilan gender. Perempuan sangat peka dan sangat perhatian terhadap kelangsungan hidup anak-anaknya, bahkan beberapa perempuan itu mengatakan bahwa sebagian perempuan yang bekerja selama dipengungsian mengatakan mereka

${ }^{6}$ Rokhmansyah.2013. "Pengantar Gender Dan feminisme". Tidak ada tempat terbit. Hal 121

${ }^{7}$ Hanani . 2017 . Keterlibatan Perempuan dalam Kepemimpinan Publik: Studi Kepemimpinan Ketua RT Perempuan di Desa Dendunn Kepulauan Riau “. Kafa'ah Journal, 7 (1), 2017, (79-92). Print ISSN 2356-0894 online ISSN 2356-0630. http:/kafaah.org/index.php/kafaah/index. Hal 89

8 Yuliana.2015."Mengurangi Tingkat Kerentanan Bencana Melalui Kebijakan Mitigasi Berbasis Kebutuhan Gender'. Hal 96 
tidak mau anaknya putus sekolah dan mengalami keterlambatan biaya hidup sekolah. Untuk itu selama di pengungsian ia harus bekerja keras untuk bisa mendapatkan penghasilan untuk anak-anak mereka. Perempuan tidak bisa menerima takdir begitu saja tetapi bisa mengsiasatinya supaya bisa melanjutkan kehidupan.

Pada kenyataan, perempuan bisa keluar dari lingkaran takdir yang menimpanya sehingga ia bisa memenuhi kebutuhan hidup keluarga. Oleh sebab itu bagaimana pun juga korban bencana harus mendapatkan pemberdayaan yang dapat melahirkan keterampilan . ${ }^{9}$ Respon akan kebutuhan hak yang didapatkan perempuan sebagai korban bencana sangat rentan dalam situasi bencana karena pada kondisi bencana akan terjadi fase krisis dalam berbagai hal membuat perempuan berada dalam kondisi lemah dan rentan.

Untuk pemenuhan kebutuhan kelompok perempuan dibedakan berdasarkan tingkatan usia mulai dari kebutuhan kelompok gadis remaja, perempuan dewasa, ibu hamil, ibu menysuai, perempuan lanjut usia. Seluruh kelompok tersebut memiliki kebutuhan yang berbeda-beda, hal yang menjadi kebutuhan pokok perempuan adalah perlindungan dan sistem keamanan yang membuat mereka nyaman. Kondisi awal merupakan perubahan dramatis bagi perempuan dimana perempuan mengalami gangguan privasi hal itu menyebabkan perempuan resah dan tidak tenang . ${ }^{10}$ Kondisi yang juga cukup memprihatinkan di saat terjadi bencana adalah tidak adanya MCK bagi warga sehingga kebutuhan akan mandi, buang air besar maupun kecil dilakukan langsung di air banjir, yang tentunya juga akan sangat mengganggu

\footnotetext{
${ }^{9}$ Hanani. Tidak ada tahun .Modul Sosiologi kebencanaan. Bukittinggi hal 99

${ }^{10}$ Hanani dkk. 2014"Perlawanan Perempuan Di Pengungsian : Studi Keberadaan. Perempuan Di Pengungsian Gunung Sinabung Kabupaten Karo Sumatra Utara". Kafaah jurnal ilmiah kajian gender No 14 No 2. Hal 146
}

kesehatan mereka, terutama bagi perempuan dan anak-anak.

Sifat bencana juga dapat meningkatkan kerentanan perempuan. Misalnya, kesehatan produksi dan kesehatan seksula, yang tidak pernah terpantau oleh dinas kesehatan. Pasca banjir banyak ibu mengalami penyakit gatal pada kemaluannya. Ibu-ibu merasa malu dan tabu untuk menceritakan masalahnya berkaitan dengan kesehatan reproduksi dan kesehatan seksual pada tim penangulangan bencana . Mereka hanya menunjukakan penyakit gatalgatal di badan, diare dan muntaber, tanpa menyebutkan masalah kesehatan reproduksi dan kesehatan seksual yang dideritanya.

Perempuan memainkan peran penting di kala bencana, karena tetap menjalankan tugas dan fungsinya care giver dalam keluarga, mereka juga seringkali berperan sebagai kepala keluarga dan pencari nafkah utama, tulang punggung keluarga, terutama ketika ia harus menjadi orang tua tunggal karena suami meninggal dunia akibat bencana . Tanaman padi hanyut dan ikan di tambak banyak yang hilang, maka suami tidak memiliki pekerjaan sama sekali. Tidak jarang perempuan juga terlibat kegiatan sosial seperti membantu di dapur umum dan pos kesehatan. Dalam kajian perempuan dengan pendekatan gender, perlu dijelaskan bahwa antara gender dan fitrah manusia itu berbeda, tidak sama. Secara seksual dan biologis, perempuan dan laki-laki memang berbeda, dan realitas ini tidak dapat dibantah. ${ }^{11}$ Tetapi dari segi gender, perempuan dan laki-laki diakui memiliki kesadaran dan kemampuan yang sama, dalam arti sama-sama bisa dikerjakan atau dimunculkan oleh keduanya.

Ada beberapa dilematis yang dihadapi oleh perempuan di pengungsian, di antaranya adalah dilema proses biologisitas. Perempuan di pengungsian, baik disadari maupun tidak oleh pihak manpun, ternyata ketika

11 Puspitawati.2013. Konsep, Teori Dan Analisis Gender. Tidak ada tempat terbit. Hal 67 
menghadapi siklus menstruasi bulanan mengalami kendala dalam merawat kehidupannya yang lebih sehat. ${ }^{12}$ Perlindungan hak-hak perempuan saat ini seharusnya sudah tidak perlu menjadi persoalan lagi, mengingat hal ini telah memiliki dasar hukum yang kuat. Di dalam peraturan perundang-undangan mengenai penaggulangan bencana pun telah dinyatakan bahwa kelompok perempuan sebagai salah satu kelompok rentan yang dalam proses recovery mendapat perlakuan dan pendekatan secara khusus.

Penyelenggaraan berbagai macam program penanggulangan bencana secara adil gender akan menjadi sulit untuk dilaksanakan apabila pemerintah sebagai pihak penetu kebijakan tidak cukup sensitive terhadap masalah yang diami perempuan. Dengan melibatkan perempuan dalam setiap prosesnya, yaitu mulai dari perencanaan, penyelenggaraan, hingga pada proses evaluasi. Dengan demikian, sensitivitas gender akan dapat disuarakan dan masyarakat pun akan dapat teredukasi, khususnya mengenai kesetaraan dan keadilan gender.${ }^{13}$ Ketidak mampuan yang dimiliki oleh perempuan karena adanya budaya yang menghambat diri kaum perempuan, budaya dan interprestasi agama selalu dijadikan senjata untuk melumpuhkan keberadaan perempuan. Fakta yang terjadi pada tsunami aceh pada tahun 2004 hampir mayoritas pemimpin agama lokal mempercayai kejadian tersebut akibat perempuan didaerah tersebut telah berdosa atau melanggar peraturan agama. Akibat dari tekanan sosial dan norma yang terus merambat pada berbagai aspek kehidupan perempuan.

${ }^{12}$ Hanani dkk. 2014"Perlawanan Perempuan Di Pengungsian : Studi Keberadaan Perempuan Di Pengungsian Gunung Sinabung Kabupaten Karo Sumatra Utara". Kafaah jurnal ilmiah kajian gender No 14 No 2. Hal 150

13 Ananda Dkk. 2014.'Perlindungan Perempuan Korban Bencana". Jurnal Mahasiswa Program Studi Sarjana Kesejahteraan Sosial Universitas Padjadjaran. Departemen Kesejahteraan Sosial. Vol 9. No . ISSN:2339/0042 (p) ISSN:2528/1577 (e) hal 115
Banyaknya kehilangan materil akibat dari bencana hal ini mengharuskan perempuan unuk memiliki andil dalam membantu ekonomi keluarga. Guncangan yang dialami keluarga akibat dari bencana menjadi suatu beban mental bagi perempuan yang memikul tanggung jawab sebagai seorang ibu. Dalam situasi bencana kesempatan untuk bekerja bagi kelompok perempuan sangat minim. Banyak diantara perempuan dan anak perempuan terpaksa menjadi buruh atau pekerja kasar yang memiliki upah sangat minim, dibeberapa daerah, perempuan korban bencana kemudian menjadi seorang pelacur untuk mendapatkan penghasilan demi menompang kehidupan keluarga. Hal itu dilakukan karena tekanan ekonomi dan tekanan tambahan sebagai orang buangan.

Perempuan memiliki peran yang strategis dalam menghadapi bencana agar resiko yang ditimbulkan akibat bencana dapat dikurangi, dalam upaya meningkatkan peran perempuan dalam mitigasi bencana, dan untuk meningkatkan peran perempuan dalam mengurangi resiko bencana:

1. Perlu adanya kesadaraan perempuan dalam memahami kondisi lingkungan dan ancaman bahaya

2. Pemahaman tentang kerentangan dan kemampuan untuk mengukur kapasitas yang dimiliki perempuan

3. Kemampuan menilai resiko bencana yang dihadapi perempuan sebagai individu, anggota keluarga dan masyarakat

4. Kemampuan untuk merencanakan dan melakukan tindakan tetentu dalam mengahdapi dan mengurangi resiko bencana.

5. Kemampuan perempuan untuk memantau, mengevaluasi dan menjamin keberlangsungan upaya penanggulangan 
resiko bencana yang dapat dikurangi atau diatasi ${ }^{14}$

Dampak bencana yang melanda suatu daerah suatu di wilayah memiliki karakter yang berbeda dan tergantung kepada tingkat kesiapan, ketahanan, dan kapasitas untuk melakukan pemulihan yang terjadi pasca bencana tak jarang memusnahkan banyak harapan di masa depan, mengingat banyaknya korban jiwa musnahnya harta benda, lenyapnya sumber pendapatan, dan rusaknya sistem sosial di masyarakat. Ketika suatu bencana melanda suatu wilayah dampak yang ditimbulkan beragam meliputi kerentanan sosial, merasuknya kesejahteraan ancaman terhadap mata pencaharian dan ketahanan pangan, hilangnya perlindungan diri sendiri, hilangnya perlindungan sosial, menurunya derajat kesehatan, hilangnya harta benda, kekacauan jaringan sosial dan kelembagaan. ${ }^{15}$ Berdasarkan kajian yang dilakaukan oleh Oxfam 2006, sebagaian besar dari korban (60 sampai $70 \%$ ) adalah perempuan, anak-anak dan lanjut usia, hal ini terjadi pada bencana alam dan bencana sosial. Dengan kondisi demikan perlu dilakukan penangana bencana secara holistic dan tidak mengesampingkan perbedaan gender dan jenis kelamin pada setiap tahapan penangana bencana dari tahap darurat sampai kepada tahap rekonstruksi pasca terjadinya bencana. ${ }^{16}$ Penanganan bencana pada saat ini cenderung didasarkan pada sudut pandang laki-laki. Kerentangan yang dialami oleh perempaun dalam situasi bencana dapat dikelompokan dalam dua

14 Hastuti.2016."Peran Perempuan dalam Menghadapi Bencana Di Indonesia".Jurusan Pendidikan Geografis FIS UNY Geomedia.vol 14.no 2.. hal 98

15 Hastuti.2016."Peran Perempuan dalam Menghadapi Bencana Di Indonesia".Jurusan Pendidikan Geografis FIS UNY Geomedia.vol 14.no 2.. hal 101

16 Hidayati, Dkk.2012 ."Akses dan Keterlibatan Perempuan dan Laki-laki dalam Penanganan Bencana dalam Pengelola berbasis Gender": Pembelajaran dari Gempa Bantul 2006. Editor Deni Hidayati. Jakarta :PT Dian Rakyat dan PPK/LIPI.ha 46 tahapan, yaitu pada saat terjadi bencana dan setelah terjadi bencana atau masa recorvery. Pada saat terjadinya bencana, posisi perempuan tidak diuntungkan sama sekali .

Pada saat terjadinya bencana tsunami 2004, misalnya sebagain besar korban yang tewas adalah perempuan dan tidak dapat dipisahkan dari anak-anak yang masih kecil atau dalam posisi mesih mendekap anaknya. Banyak pihak yang mengatakan bahwa banyak perempuan yang menjadi korban disertai oleh anak-anak . Hal ini dikarenakan perempuan tidak dapat berlari leih cepat untuk meningggalkan rumah tanpa kepastian apakah anak-ankanya sudah selamat atau belum. Perempuan tidak hanya memikirkan bagaimana dia selamat, tetapi dia juga memikirkan bagaimana dia harus menyelamatkan anak-anak dan keluargnya. ${ }^{17}$ Perempuan tidak kuasa untuk dapat berlari cepat karena dia harus mengendong anaknya atau mengandeng anknya, sementara kecepatan gelombang tsunami melebihi kecepatan seorang ibu berlari. Tidak sedikit di antara korban bencana mengatakan bahwa mereka tidak kuat melihat kondisi kampung halamannya yang dihantam bencana. Dengan linangan air mata, mereka menceritakan dengan penuh kesedihan tentang bagaimana kondisi lingkungan dan keluarga mereka.

Kerentanan perempuan pada masa recorvery berkaitan erat dengan tidak terpenuhinya hak-hak perempuan. Pemenuhan kebutuhan paska bencana cenderung menyamakan antara kebutuhan laki-laki dan perempuan. Di pengungsian, tidak bisa diabaikan adanya frustasi yang melanda para pengungsi, karena begitu cepat terjadinya proses perubahan dinamikan kehidupan pengungsi dari kondisi awalnya. ${ }^{18}$ Banyak

17 Nurtjahodkk. 2011. "Peran Perempuan dalam Pembangunan Berkelanjutan Woment In Susti Nable Development". Tidak ada tempat terbit, hal 99

${ }^{18}$ Hanani dkk. 2014"Perlawanan Perempuan Di Pengungsian : Studi Keberadaan Perempuan Di Pengungsian 
kebutuhan khusus perempuan yang terlewatkan, Karena tidak dianggap sebagai kebutuhan mendesak.

Enarson di dalam ${ }^{19}$ mengatakan bahwa gender membentuk dunia sosial yang didalamnya, dimana berbagai peristiwa alam terjadi. Perempuan dibuat lebih rentang terhadap bencana melaluai peran sosial yang mereka bangun. Dan perempuan memilki sedikit akses terhadap sumberdaya, seperti jaringan sosial, transportasi, informasi, keterampilan, control sumberdaya alam dan ekonomi, mobilitas individu, jaminan tempat tinggal dan pekerjaan yang bebas dari kerasan dan memegang kendali dalam mengambil keputusan. Padahal itu semua penting dalam kesiapsiagaan dalam mengantisipasi bencana, mitigasi dan rehabilitas paska bencana.

Kebutuhan untuk menginterpretasikan gender dalam pengelolaan bencana adalah suatu bentuk memastikan bahwa skema kesiapsiagaan dan antisipasi bencana, hingga kemudian kemampuan untuk melakukan pemulihan dari dampak bencana, bisa dimiliki secara merata antara jenis kelamin dan umur. Dengan terpenuhinya hak semua orang maka akan mengantisipasi munculnya bencana baru yang akan menambah beban dan dampak yang dirasakan terutama oleh kelompok rentan seperti perempuan.

Sejak dilakukan konferensi perempuan sedunia pada tahun 1995 di Beijing, pengarusutamaan gender dijadikan sebagai strategi utama utuk memastikan bahwa isu-isu gender dimasukkan ke dalam bidang dan sector pembangunan untuk mendorong kesetaraan gender. Menindaklanjuti hasil dari konferensi tersebut, pemeritah Indonesia

Gunung Sinabung Kabupaten Karo Sumatra Utara". Kafaah jurnal ilmiah kajian gender No 14 No 2. Hal 153

${ }^{19}$ Hidayati, Dkk.2012 ."Akeses dan Keterlibatan Perempuan dan Laki-laki dalam Penanganan Bencana dalam Pengelola berbasis Gender": Pembelajaran dari Gempa Bantul 2006. Editor Deni Hidayati. Jakarta :PT Dian Rakyat dan PPK/LIPI. Hal 65 mengeluarkan intruksi presiden (Inpres) No 9 tahun 2000 tentang pentingnya strategi pengrusutamaan gander dalam berbagai kebijakan pembangunan di Indonesia. Pengurusutamaan gender ini telah rinci terdapat dalam RPJMN tahun 2004

Pengarustamaan gender dalam kesiapsiagaan dan respon bencana, mencangkup upaya untuk meninjau dan menganalisis situasi melalaui perspektif gender. Dal hal ini stratrgi-strategi dan prakarsaprakarsa berkaitan dengan penanggulangan bencana disusun untuk memenuhi kebutuhan laki-laki dan perempuan yang melibatkan keduanya dalam proses pengembangan, implementasi, montoring dan evaluasi. ${ }^{20}$ Beberapa kajian telah dilakukan untuk mengembangkan kerangka kerja (framework) tantangan pengarusutamaan gender dalam penanganan bencana. Berdaasrkan kerangka kerja yang dikembangkan tersebut dapat dibagi menjadi tiga strategi yang perlu dicermati yaitu: pengarusutamaan gender dalam kelembagaan, institusi dan kebijakan; penekanan pentingnya pentingnya management data dan informasi yag sangat sensitive gender dan peningkatan kesadaran tentnag relasi gender dan bencan, serta pengembangan kapsitas perempuan.

Berkaitan dengan kelembagaan dan kebijakan upaya dalam penanganna bencana yang terjadi perlu adanya paung hukum dengan disyahkan UU No 24 tahun 2007 tentnag penanganan bencana nasional. Kepedulian peremintah terhadap pentingnya penanganan bencana ini juga didukung oleh adanya rencana aksi nasional penggurangan resiko bencana 2009-2014, sebagai salah satudokumen acuan yang berkaitan dengan kebencanaan di Indonesia.Bersamaan dengan itu dibentuk pula Badan Penangulangan Bencana Nasional (BNBP). Dengan adanya undang-undang penangulangan bencana rencana aksi dan terbentuknya badan tingkat

${ }^{20}$ Jhonson. 1986. Teori Sosiologi Klasik dan Modern. Jakarta. PT Gramedia.hal 120 
nasional diharapkan setiap (provinsi dan kabupaten), terutama di daerah yang rawan bencana untuk membentuk Badan Penangulangan Bencana Daerah (BPBD) dan membuat rencana aksi daerah yang sesuai dengan potensi kawasan dan ancaman bencana yang ada pada masing-masing daerah.

UU No 24 Tahun 2007 tentang penanggulangan bencana dan Inpres No 9 Tahun 2000 tentang pengarusutamaan gender dalam kebijakan dapat dipakai sebagai acuan untuk mengembangkan kebijakna penanggulangan bencana yang sinergi dengan harus pengutamaan gender. ${ }^{21}$ Diharapkan kebijakan penanggulangan bencana yang dikembangkan oleh daerah masing-masing mengunterpretasikan isu-isu gender di tingkat lokal di daerah masing-masing. Oleh karena itu pengarusutamaan gender bukan lagimenjadi suatu bagain yang teepisahkan dari kerangka acuan dalam menganalisis perumusan dan pengambilan kebijakan.

Hasil pusat kajian penelitian kependudukan ${ }^{22}$ menunjukan bahwa penangulangan bencana berbasis gender meninjukakan adanya suatu ketimpangan relasi perempuan dan laki-laki dalam berbagai aspek kehidupan sehari-hari dan hal itu tentu akan berpengaruh terhadap penanganan bencana bagi kaum perempuan. Perempuan seringkali tidak dilibatkan dalam pengelolaan evakuasi, distribusi bantuan, sehingga program rehabilitas dan rekonstruksi paska bencana. Perempuan lebih diperlakukan sebagai korban bencana yang diabaikan peran sentralnya.

Peran gender cukup tinggi kaitanya dengan penanggulangan bencana yang dilakukan oleh

${ }^{21}$ Ulil . 2011 "Penanganan Anak Dalam Masa Tanggap Darurat Bencana Alam: Tinjanan Konvensi Hak. Anak Dan Undang-Undang Perlindungan Anak". Fakultas dakhwah UIN Sunan Kalijaga Yogyakarta. Vol XI, No 1. Hal 78

${ }^{22}$ Hidayati, Dkk.2012 ."Akses dan Keterlibatan Perempuan dan Laki-laki dalam Penanganan Bencana dalam Pengelola berbasis Gender": Pembelajaran dari Gempa Bantul 2006. Editor Deni Hidayati. Jakarta :PT Dian Rakyat dan PPK/LIPI. Hal 70 masyarakat sekitar, terutama pada masa kritis 1-7 hari pasca terjadinya bencana. Akan tetapi peran perempuan akan menjadi lebih berkurang ketika penanganan bencana telah didominasi oleh pemerintah dan steakholder lain. Kondisi ini diindikasi dari minimnya akses dan keterlibatan perempuan dan laki-laki dalam penanggulangan bencana serta kurangnya kebijakan dan program bencana yang sangat sensitif gender.

Perempuan masih kurang mendapat akses untuk memenuhi kebutuhan perempuan, terutama pada masa krits darurat bencana tiga sampai seminggu setelah bencana. Perempuan tidak memiliki peran dalam pengelolaan tempat pengungsian, seperti mengatur tata pengelolaan tempat pengungsian, membuat sekat-sekat pemisah antara laki-laki dan perempuan atau sekat-sekat untuk keluarga, seperti sekat-sekat untuk rumah sakit atau pemisah untuk saran MCK bagi laki-laki dan perempuan. ${ }^{23}$ Penanggulan bencana pasca terjadnya bencana masih sangat kurang sensitive gander. Hal ini diindikasikan oleh belum adanya pilahnya korban bencana menurut jenis kelamin dan umur sehingga jumlah korban dari kelompok rentan dan perempuan tidak diketahuai. Program dan kegiatan penanganan bencana juga belum menyatakan data menurut jenis kelamin.

Upaya untuk meningkatkan peran gender dalam penangulangan bencana pada saat ini masih sangat diperlukan karena Indonesia merupaka wilayah yang sangat rentan bencana alam. Kajian dan kebijakan berbasis gender memberikan beberapa alternative gagasan untuk peningkatkan peran perempuan, terutama yang berkaitan dengan akses dalam keterlibatan perempuan dan lakilaki, serta kebijkan dan program dalam

${ }^{23}$ Hanani 2017 “ Keterlibatan Perempuan dalam Kepemimpinan Publik: Studi Kepemimpinan Ketua RT Perempuan di Desa Dendunn Kepulauan Riau “. Kafa'ah Journal, 7 (1), 2017, (79-92). Print ISSN 2356-0894 online ISSN 2356-0630. http:/kafaah.org/index.php/kafaah/index. Hal 84 
penanggulangan bencana yang sangat sesnsitif gender.

Berbicara persoalan perempuan tentu tidak bisa dilepaskan dari dari gambaran keuletan, keteguhan, dan juga pengapdian. Walaupun secara fisik tidak sama dengan lakilaki dengan perempuan. Namun dibalik itu perempuan lebih banyak memilki kapsitas dari pada laki-laki.Dibalik kerasnya sistem sosial ekonomi di masyarakat, banyak perempuan yang mampu untuk membuktikan bahwa kesanggupan untuk bertahan hidup. ${ }^{24}$ Banyak dari perempuan yang menjadi perempuan tanguh yang tidak hanya berdiam diri untuk mengurusi anak dan rumah tangganya di tengah segala keterbatan yang dimilikinya.

Tentu hal itu menjadi potensi yang harus dilirik oleh bayak pihak yang bisa difungsikan sebagai pembantu dalam penangulangan bencana. Bukan hanya persoalan itu, perempuan memilki keefektifan dalam berkomunikasi publik juga sudah dapat dibuktikan. Dalam hal pengorganisasian perempuan mereka dalam berkomunikasi akan terlihat nyata ketika mereka membaur sesama mereka.

Pengorganisasian yang dibentuk oleh perempuan sangat bermanfaat untuk kepentingan dalam megurangi resiko bencana.Karena perempuan lebih sering untuk berada dilingkungan domestic. Maka potensi itu akan sangat berguna untuk penyebarluasan informasi da komunikasi tentang bencana. Selain itu perempuan juga bisa dijadikan kelompok komunal yang yang bisa difungsikan sebagai suatu media konsolidasi, saling membagi informasi dan untuk berkoordinasi.

Ditempat-tempat seperti inlah mereka saling berbagi pengalaman, pengetahuan dan sekaligus mempererat jalinan silaturahmi.Luar

${ }^{24}$ Hanani dkk.2018 "Dakhwah Mitigasi Bencana Di Lereng Merapi Studi Kasus Pemberdaaan Masjid Berbasis Mitigasi Sungai Pua Kabupaten Agam Sumatra barat". Kontekstualitas.jurnal penelitian sosial dan keagamaan. Vol 3301 P-ISSN:1979-598xe.-ISSN:2548-1770. Hal 30 biasa jika potensi tersebut dikembangkan. Untuk itu potensi perempuan dalam penanggulangan bencana perlu untuk lebih diberdayakan melalauai beragam kegiatan yang lebih bermuara kepada peningkatan kapasitas. ${ }^{25}$ Akan lebih menarik juga peningkatan kapasitas perempuan juga diberangi dengan berbagai kajian kearifan lokal (local wisdom) dan simulasi kebencaan yang masif.Paling tidak harus mendapatkan pengetahua dasar standar penyelamatan dan juga pemahaman tentang rute evaluasi.

Dengan adanya peningkatan kapasitas perempuan diharapkan akan berdampak positif dalam mengurangi jatuhnya korban saat bencana. Pemberdayaan kelompok komunal ini juga berfungsi sebagai alat untuk menamankan nilai-nilai kepada masyarakat tentang pentingnya menjaga lingkungan.

Pada saat ini sudah banyak perempuan yang terbebas dari stereotype yang berkaitan dengan pelemahan peran perempuan.Bisa kita dilihat pada realitas pada saat sekarang ini banyak peran yang biasa diperankan oleh lakilaki bisa dipercaya diperankan oleh perempuan. Namun jumlah "banyak" tersebut belum mencapai kata "sejajar".

Hubungan antara bencana dan gender baik pada pra, saat dan pasca bencana, apabila disepakati sangat banyak perempuan yang dirugikan. Perbedaan korban bencana laki-laki dan perempuan sangat erat kaitanya dengan gender. Ketika bencana alam perempuan banyak menjadi korban sebagain dari mereka kebanyakan berada di antara tengah dan dalam rumah. Sedangkan ketika bencana perang laki-laki banyak menjadi korban karena selalu inggin mengambil peran terdepan dengan alasan mereka membela kelompok, wilayah dan harga diri mereka.

${ }^{25}$ Hanani. 2016. " PerlindunganPerempuan Lanjut Usia Korban Bencana Gempa Bumi Melaluai Tradisi Sumbayang 40 Di Sumatra Barat'. Kafa'ah: Jurnal kajian gender Vol. 4 No 1.hal 21 
Dalam penanggulangan banjir pada saat itu paling banyak melibatkan perempuan, terutama dalam mengambil kebijakan maupun menerapkan strategi penanggulangan bencana. Pada saat terjadinya bencana perempuan dilibatkan dalam penanganan akan tetapi banyak mereka bertugas di dinas-dinas pemerintahan. Sedangkan perempuan dari masyarakat biasa belum ada bahkan untuk terlibat dalam berbagai pelatihan tanggap darurat bencana sekalipun. Kalau ada perempuan yang terlibat dalam penanganan bencana keterlibatannya hanya jika terjadi bencana banjir yaitu bertugas sebagai pengelola bahan makanan, Sedangkan yang lain dikerjakan oleh laki-laki. Adapun perempuan yang dilibatkan juga bukan dari penduduk dari korban bencana akan tetapi dari dinas-dinas pemerintahan maupun para relawan. ${ }^{26}$ adapun hak anak dalam masa tanggap darurat :

1. Hak sipil dan kemerdekaan ada dua hak dasar anak yang harus diperhatikan terkait dengan hak sipil dan kemerdekan dalam tanggap darurat yaitu :

a. Hak atas pencatatan kelahiran dan identitas. Dalam situasi paca bencana kehancuran intrastruktur dan kelumpuhan sistem administrasi negara sampai ditingkat RT, membuat anakanak lahir pasca gempa tidak tercatat. Hal ini menempatkan anak-anak dalam situasi kehilangan hak akibat tidak tercatat dalam mekanisme pencatatan kelahiran.

b. Hak atas kebebasan beragama. Dalam situasi pasca bencana,bantuan kemanusian baik fisik maupun bersifat dokumen psikologis harus ditujukan kepada semua orang tanpa memandang keyakinan agama. Situasi pasca bencana sangat mudah dijumpai pemberi bantuan kemanusian yang laindimanfaatkan bila

\footnotetext{
${ }^{26}$ Puspitawati.2013. Konsep, Teori Dan Analisis Gender. Tidaka da tempat terbit. Hal 78
}

secara langsung maupun terselubung untuk memaksakan keyakinan agama pada korban, termasuk anak-anak.

2. Lingkungan keluarga dan pengasuhan alternatif

a. Hak atas bimbingan orang tua. Dalam siuasi pasca bencana, kehidupan yang serba darurat sering membuat orang tua kehilangan kontrolatas pengasuhan dan bimbingan terhadap mereka. Keadaan ini dapat mengancam perkembangan mental moral dan sosial anak, sekaligus menempatkan anak dalam posisi rentan terhadap kemungkinan tindak eksploitasi, penculikan, kekerasan, dan perdangangan.

b. Hak untuk tidak di pisahkan dan penyatuan kembali dengan orang tua. Dalam situasi pasca bencana, anak-anak dapat dpisahkan dari orang tua mereka. Kemungkinan situasi keterpisahan bersifat permanen atau temporer hingga orang tua kelak ditemukan.

3. Kesehatan dan kesejahteraan dasar

a. Hak khusus anak difabel dengan orang kecacatan. Pada saat dan pasca bencana, anak-anak difabel berada dalam keretanan khusus karena situasi kecacatan mereka. Saat terjadi bencana mengalami kesulitan untuk menyelematkan diri.

b. Hak atas layanan kesehatan. Pada saat dan pasca bencana, anak-anak dihadapkan pada situasi yang dapat mengancam tingkat kesehatan mereka. Hancur dan rusaknya fasilitas sanitasi, luka-luka akibat bencana alam atau pun lingkungan buruk pasca bencana alam menyebabkan menurunnya tingkat kesehatan anak ${ }^{27}$

Laki-laki dan perempuan dapat memainkan peran yang saling melengkapi pada

27 Hastuti.2016."Peran Perempuan dalam Menghadapi Bencana Di Indonesia".Jurusan, Pendidikan Geografis FIS UNY Geomedia.vol 14.no 2.hal 90 
masa pemulihan pasca terjadinya bencana. Laki-laki umumnya melakukan rekontruksi fisik sementara perempuan berkontribusi untuk memperluas dukungan psikososial dan difersifikasi mata pencaharian. Kesadaran dan pengetahuan perempuan sangat penting untuk manajemen resiko yang efektif dalam mempesiapkan rumah tangga, menyimpan stok makanan dan mempertahankan jaringan sosial umtuk penyebaran informasi, pendidikan anak dan masyarakat

Bencana memang bukanlah sesuatu hal yang dapat untuk dihindari kedatangannya, namun penanggulangannya dapat diupayakan lebih baik sehingga tidak semakin memperburuk keadaan. Penanggulangan bencana yang selama ini dilakukan di Indonesia masih sangat komprehensif, ini terbukti dari banyaknya temuan di lapangan yang masih sangat kurang respontifnya pola penanggulangan bencana dengan sangat tidak kesetaraan gender. Jika suatu penanggulangan bencana telah di lakukan secara komprehersif, tentu saja segala aspek terkecil yang terjadi di dalam masyarakat dapat dipertimbangkan dan dicarikan jalan keluarnya. ${ }^{28}$ Generalisasi atau penyamarataan dalam penanggulangan bencana tidak dapat dipraktekkan dalam korban bencana laki-laki dan perempuan meskipun dalam keadaan darurat. Penanggulangan bencana yang komprehensif justru seharusnya lebih respontif gender demi menciptakan pola penanggulangan yang baik yang tidak memilki dampak berkepanjangan bagi kaum perempuan, terlebih lagi pasca terjadinya bencana.

\section{Kesimpulan}

Bencana alam banyak menimbulkan dampak buruk pada keluarga miskin, yang memiliki lapangan pekerjaan dan penghasilan yang tidak tetap dan tidak jelas. Bencana alam akan memiskinkan orang miskin. Jenis

28 Widayatun.2006,"Pengelola Bencana Berbasis Gender: Pembelajaran Dari Gempa Bantul". Tidak ada tempat terbit . hal 54 pertolngan dan bantuan hendaknya diarahkan kepada terbagunnya kepada kemandirian masyarakat.

Program penanganan bencana masih mengacu kepada stereotype bias gender, yaitu kebijakan penanggulangan bencana seringkali menempatkan laki-laki pada peran gendernya sebagai kepala keluarga, serta menempatkan peran perempuan sebagai ibu rumah tangga, mengurus kegiatan domesitik. Hal ini merupakan hambatan bagi kaum perempuan, untuk tidak pernah dilibatkan seperti dalam pelatihan penanganan bencana, sehingga akses untuk mendapatkan informasi tidak tidapatkan secara langsung, atau melalui orang lain. Perlindungan hak-hak perempuan saat ini sehaarusnya sudah tidak perlu menjadi persoalan lagi, mengingat hal ini telah memiliki dasar hukum yang kuat.

Di dalam peraturan perundanganundangan mengenai penanggulangan bencana pun telah dinyatakan bahwa kelompok perempuan sebagai salah satu kelompok rentan yang dalam proses recovery mendapat perlakuan dan pendekatan secara khusus.

\section{Daftar Pustaka}

Ananda Noyameta Dkk. 2014."Perlindungan Perempuan Korban Bencana". Jurnal Mahasiswa Program Studi Sarjana Kesejahteraan Sosial Universitas Padjadjaran. Departemen Kesejahteraan Sosial. Vol 9. No . ISSN:2339/0042 ISSN:2528/1577 (e)

Enarson, E.2000. "Gender ekuiliti work and and disaster reduction: making the connection.

Hanani Sifia dkk.2018 'Dakhwah Mitigasi Bencana Di Lereng Merapi Studi Kasus Pemberdaaan Masjid Berbasis Mitigasi Sungai Pua Kabupaten Agam Sumatra barat”. Kontekstualitas.jurnal penelitian sosial dan keagamaan. Vol 3301 P-ISSN:1979-598xe.ISSN:2548-1770 
Hanani Silfia. Tidak ada tahun .Modul Sosiologi kebencanaan. Bukittinggi

Hanani Silfia dkk. 2014"Perlawanan Perempuan Di Pengungsian : Studi Keberadaan Perempuan Di Pengungsian Gunung Sinabung Kabupaten Karo Sumatra Utara". Kafaah jurnal ilmiah kajian gender No 14 No 2

Hanani Silfia. 2016. "PerlindunganPerempuan Lanjut Usia Korban Bencana Gempa Bumi Melaluai Tradisi Sumbayang $40 \mathrm{Di}$ Sumatra Barat'. Kafa'ah: Jurnal kajian gender Vol. 4 No 1

Hanani Silfia. 2017 “ Keterlibatan Perempuan dalam Kepemimpinan Publik: Studi Kepemimpinan Ketua RT Perempuan di Desa Dendunn Kepulauan Riau ". Kafa'ah Journal, 7 (1), 2017, (7992). Print ISSN 2356-0894 online ISSN 2356-0630. http:/kafaah.org/index.php/kafaah /index

Hastuti.2016."Peran Perempuan dalam Menghadapi Bencana Di Indonesia".Jurusan Pendidikan Geografis FIS UNY Geomedia.vol 14.no 2.

Hidayati, Inayah Dkk.2012 ."Akses dan Keterlibatan Perempuan dan Laki-laki dalam Penanganan Bencana dalam Pengelola berbasis Gender": Pembelajaran dari Gempa Bantul 2006. Editor Deni Hidayati. Jakarta :PT Dian Rakyat dan PPK/LIPI.

Jhonson Doyle Paul. 1986. Teori Sosiologi Klasik dan Modern. Jakarta. PT Gramedia

Rokhmansyah.2013. "Pengantar Gender Dan feminisme". Tidak ada tempat terbit

Nurtjaho Dewi dkk. 2011. "Peran Perempuan dalam Pembangunan Berkelanjutan Woment In Susti Nable Development". Tidak ada tempat terbit

Puspitawati, Herien.2013. konsep, teori dan analisis gender. Tidaka da tempat terbit

Ulil Absor, M. 2011 "Penanganan Anak Dalam Masa Tanggap Darurat Bencana Alam: Tinjauan Konvensi Hak Anak Dan Undang-Undang Perlindungan Anak".
Fakultas dakhwah UIN Sunan Kalijaga Yogyakarta. Vol XI, No 1

Yuliana Sri.2015."Mengurangi Tingkeat Kerentanan

Bencana Melalui Kebijakan Mitigasi Berbasis Kebutuban Gender".

Widayatun.2006,"Pengelola Bencana Berbasis Gender: Pembelajaran Dari Gempa Bantul". Tidak ada tempat terbit 